J. Oral Biosci. 51(1) : 31-45, 2009

\title{
ORIGINAL
}

\section{Profiling of Differentially Expressed Genes in Peri-implantitis and Periodontitis in vivo by Microarray Analysis}

\author{
Matthias Roediger ${ }^{1)}$, Xavier Miró ${ }^{2)}$, Robert Geffers ${ }^{3)}$, Malte Irmer ${ }^{1)}$, Alfons Huels ${ }^{1)}$, \\ Nicolai Miosge ${ }^{1)}$ and Nikolaus Gersdorff ${ }^{1) \S}$ \\ 1) Department of Prosthodontics, Georg-August-University Goettingen \\ ${ }^{2)}$ Institute of Molecular Psychiatry, Life \& Brain Center, Universitaetsklinikum Bonn \\ 3) Department of Cell Biology and Immunology, German Research Center for Biotechnology \\ 1) D-37075 Goettingen, Germany \\ ${ }^{2)}$ D-53127 Bonn, Germany \\ ${ }^{3)}$ D-38124 Braunschweig, Germany
}

〔Received on December 11, 2008 ; Accepted on February 18, 2009]

Key words : microarray analysis / real-time RT-PCR / inflammation / PDL / peri-implant tissue

\begin{abstract}
The purpose of this study was to compare gene expression profiles of peri-implantitis and periodontitis to elucidate potential differences at the molecular level. With the help of microarray analysis, genome-wide gene expression of inflamed peri-implant granulation tissue, inflamed and healthy periodontal tissues ( $\mathrm{n}=48$ patients) were compared and the data were validated by real-time reverse transcription polymerase chain reaction. After highlighting different gene classes, we focused on the extracellular matrixreceptor interaction pathway and gene expression of extracellular matrix molecules, their receptors and matrix degrading enzymes. Only genes of non-fibril-forming collagens (types IV, VI, VII, and XIII) were increased in peri-implantitis compared to periodontitis, whereas the expressions of two fibril-forming collagens (types III and XI) were decreased in peri-implantitis, which suggested that peri-implant tissue remodels faster than periodontal tissue in vivo. Furthermore, cathepsin D and cathepsin S seem to participate in the destruction of peri-implant connective tissue. Despite their clinical similarities, the present investigation demonstrated that peri-implantitis and periodontitis are two different disease entities at least at the messanger ribonucleic acid level. The data provide insight for future studies aimed at dissecting the pathogenesis of peri-implant inflammation.
\end{abstract}

\section{Introduction}

The soft and hard tissues surrounding an osseointegrated implant show similarities with the periodontium in natural dentition ${ }^{1)}$. Peri-implant disease is a collective term for inflammatory reactions in the tis-

\footnotetext{
$\S$ Corresponding author

E-mail :ngersdo@gwdg.de
}

sue surrounding an implant ${ }^{2)}$. Peri-implant mucositis is a term for inflammatory reaction in the soft tissue surrounding a functioning implant, and, furthermore, peri-implantitis is a term for inflammatory reaction with loss of supporting bone in the tissues surrounding a functioning implant ${ }^{2)}$. Untreated periodontitis may ultimately lead to the loss of natural teeth and peri-implantitis can result in the loss of dental implants ${ }^{1)}$. Nevertheless, it is still unclear whether peri-implantitis differs from periodontitis at the mes- 
sanger ribonucleic acid (mRNA) level.

In bone, the extracellular matrix (ECM) composition has been extensively investigated ${ }^{3,4)}$ and plays a crucial role in bone remodelling and the osseointegration of dental implants by regulating proliferation, migration and finally differentiation of osteogenic cell population ${ }^{5)}$. Moreover, the synthesis and degradation of ECM proteins are critical not only for proper embryonic and postnatal development, but throughout adulthood in health and disease. Consequently, the roles of ECM proteins and their degrading enzymes in healthy and inflamed peri-implant tissues have to be further elucidated.

The laminins are a major family of basement membrane glycoproteins each consisting of alpha, beta, and gamma chains ${ }^{6}$. They fulfil numerous biological functions, such as tissue regeneration, cell migration, cell differentiation, cell proliferation and cell adhe$\operatorname{sion}^{7-9)}$. Currently, 5 alpha, 3 beta and 3 gamma chains can form fifteen different laminin isoforms ${ }^{6,10-12)}$.

Collagens are structural proteins that participate in the assembly of ECM polymers ${ }^{13)}$. At least 28 different types of collagens have been identified in humans ${ }^{14,15)}$. Thus, in addition to their structural roles, collagen also has numerous developmental and physiological functions.

To a large extent, the anchoring of cells to the ECM is mediated by integrins, which are heterodimeric transmembrane receptors composed of noncovalently associated alpha and beta chains ${ }^{16)}$. In higher vertebrates, the integrin family is composed of 24 alpha subunits and 9 beta subunits ${ }^{17)}$. From approximately 200 heterodimers that could theoretically form, only about 25 have been identified thus far in vivo. Of the 25 integrin heterodimers, alphalbeta1, alpha2beta1, alpha10beta1 and alpha11beta1 act as primary receptors for native collagens ${ }^{18,19)}$ and alpha3beta1, alpha6beta1, alpha7beta1, and alpha6beta4 are major laminin receptors ${ }^{20)}$.

In peri-implant as well as in periodontal diseases, microorganisms initiate and maintain the destructive processes $^{21,22)}$. In response to microbial plaque, hostmediated tissue destruction occurs, for example, via complement activation, the release of lysosomal enzymes and connective tissue matrix metalloprote- inases (MMPs $)^{22-24)}$. Furthermore, members of the a disintegrin and metalloproteinase (ADAM) family of proteins, an MMP-related metalloproteinase family, seem to be involved in the regulation of growth factor activities and integrin functions and potentially lead to the proteolytic processing of other transmembrane proteins, cell adhesion and cell signaling events. In addition, cathepsins are thought to contribute to periodontal and peri-implant tissue destruction ${ }^{25,26)}$.

Although peri-implantitis is similar to periodontitis, with respect to etiology and treatment ${ }^{1)}$, we hypothesize that both are distinct disease entities at the molecular level. For that purpose, we utilize a microarray platform to generate global messanger ribonucleic acid (mRNA) expression profiles for both peri-implant and periodontal inflammation. We highlight the ECM-receptor interaction pathway and analyze ECM molecules, their receptors and matrix degrading enzymes. The aim of the present study is to identify functional pathways involved in the pathogenesis of peri-implantitis and may elucidate possible differences between periodontitis and peri-implantitis at the mRNA level.

\section{Materials and Methods}

\section{Patient selection}

Chronically inflamed peri-implant as well as healthy and chronically inflamed periodontal tissues were collected from 48 patients at the Dental Medical School of the University of Goettingen (21 men, 27 women, aged between 18 and 72 years) from March 2005 to August 2006. Each patient provided one tissue sample, therefore, 48 tissue probes were collected. The peri-implant tissue samples were taken from 16 endosteal implants of patients suffering from peri-implantitis (Astra Tech ${ }^{\circledR}$, ITI Bonefit ${ }^{\circledR}$, or Brånemark $^{\circledR}{ }^{27)}$. The periodontal tissue probes were taken from teeth either extracted for orthodontic reasons or due to carious lesions (16 teeth with healthy periodontium) or from teeth with generalized chronic periodontitis (16 teeth with chronic periodontitis ${ }^{28)}$. Periodontal ligament (PDL) of healthy teeth had no clinical signs of inflammation (no bleeding on probing), exhibited a probing depth of $\leq 3.5 \mathrm{~mm}$ (using a 
periodontal probe calibrated in $0.5 \mathrm{~mm}$ increments) and had no radiographic detectable bone loss. In contrast, implants and teeth with generalized chronic inflammation exhibited obvious clinical signs of inflammation (bleeding on probing), exhibited a probing depth of $>4 \mathrm{~mm}$ (using a periodontal probe calibrated in $0.5 \mathrm{~mm}$ increments) and had radiographic evidence of bone loss ( 1 to $7 \mathrm{~mm}$ ). The peri-implant as well as the periodontal disease was termed chronic because only patients we were following for a 2-year period were integrated into the study and only peri-implant granulation tissue was used from implants inserted in the Dental Medical School of the University of Goettingen. Furthermore, to exclude a potential effect of pain medications prescribed right after sinus augmentation, we investigated only peri-implant granulation tissue taken from implants inserted into healthy bone without any augmentation technique. A detailed anamnesis of each patient was explored. All patients had no history of illnesses, i.e. heart diseases or diabetes, and were not on medication. In addition, the tissue samples used in our study were only taken from non-smokers. The explanted implants and extracted teeth were immediately frozen and stored at $-80^{\circ} \mathrm{C}$. All patients who participated in the study were informed about the nature and aim of this project and provided written informed consent. The study was approved according to the regulations of the Ethics Committee of the Medical Faculty of the University of Goettingen.

\section{Labelling of cRNA for gene expression analysis arrays}

The peri-implant tissue was scraped off from the middle of the inflammatory cell infiltrate overlying the explanted implant and the periodontal tissue was scraped off from the middle of the inflammatory cell infiltrate overlying the middle portion of the roots of the extracted teeth. Total RNA from chronically inflamed peri-implant tissue, chronically inflamed and healthy PDL tissue was isolated using the RNeasy mini Kit (Qiagen, Hilden, Germany), according to the manufacturer's instructions. Healthy PDL tissue was removed from the middle third of the root clearly avoiding sampling the gingiva. The chronically inflamed peri-implant and periodontal tissues were sampled directly from the middle of the inflammatory cell infiltrate, again avoiding the gingiva. Quality control and quantitation of total RNA samples were determined prior to the microarray experiments (Agilent 2100 Bioanalyzer, Agilent Technologies, Palo Alto, CA, USA). Equal amounts of total RNA of each probe were pooled into inflamed peri-implant, inflamed and healthy periodontal tissue pools. The pooled RNA was then converted to copy desoxyribonucleic acid (cDNA) using a modified oligo-dT primer with 5'-T7 RNA polymerase promoter-sequence. Then, in vitro biotin-labelled cRNA transcription was performed using T7 RNA polymerase and the cDNA template in the presence of a mixture of unlabeled nucleotides (adenosine triphosphate (ATP), cytidine triphosphate (CTP), guanosine triphosphate (GTP) and uridine triphosphate (UTP) and biotin-labelled CTP and UTP (BioArray High Yield RNA Transcript Labeling Kit ; Enzo Diagnostics, Farmingdale, NY, USA). Biotinlabelled copy ribonucleic acid (cRNA) was then purified on microspin columns provided with the RNeasy Mini Kit and fragmented according to Affymetrix's (Santa Clara, CA, USA) protocol. The amount of labelled cRNA was determined by measuring the absorbance at $260 \mathrm{~nm}$.

\section{Hybridization and scanning of gene expres- sion analysis arrays}

To monitor the relative abundance of mRNA for full-length human genes, the Affymetrix GeneChip HG_U133A 2.0 was used, representing 22,283 probe sets (14,239 unique human genes). Labelled cRNA, fragmented to an average size of $100-150$ bases, was hybridized to the GeneChips. For each pool of cRNA, two GeneChips were hybridized. Hybridization was performed at $45^{\circ} \mathrm{C}$ for $16 \mathrm{~h}$, after which the arrays were washed in an automated Affymetrix fluidic station. Hybridized cRNA was fluorescently labelled by adding streptavidin-phycoerythrin (Molecular Probes, Eugene, OR, USA). Stained arrays were then scanned in a Hewlett-Packard Gene Array Scanner (Agilent Technologies). A complete list of genes present on HG_U133A 2.0 can be found in the Affymetrix database at http://www.affymetrix.com 
Table 1 Primers for real-time RT-PCR analysis

\begin{tabular}{|c|c|c|c|c|c|}
\hline Transcript & $\begin{array}{l}\text { Annealing } \\
\text { temperature }\end{array}$ & Forward primer & Reverse primer & Length & $\begin{array}{c}\text { Accession } \\
\text { number }\end{array}$ \\
\hline Collagen type IV & $61.0^{\circ} \mathrm{C}$ & ggagataaaggggctcaagg & tttttcacccggtaatccag & 189 bp & $\begin{array}{c}\text { NM_001845 } \\
\text { (GenBank) }\end{array}$ \\
\hline Integrin beta 1 & $56.0^{\circ} \mathrm{C}$ & ctgattggctggaggaatg & tttctggacaaggtgagca & 186 bp & $\begin{array}{l}\text { BC020057 } \\
\text { (GenBank) }\end{array}$ \\
\hline Integrin beta 4 & $57.9^{\circ} \mathrm{C}$ & gcttcacacctatttccctg & gacccagtcctcgtcttctg & 186 bp & $\begin{array}{c}\text { NM_000213 } \\
\text { (GenBank) }\end{array}$ \\
\hline Integrin alpha 6 & $53.1^{\circ} \mathrm{C}$ & gcgtcccattcccataact & tcgtctccacatccetctt & $156 \mathrm{bp}$ & $\begin{array}{c}\text { NM_000210 } \\
\text { (GenBank) }\end{array}$ \\
\hline HPRT1 & $61.0^{\circ} \mathrm{C}$ & tgacactggcaaaacaatgca & ggtccttttcaccagcaagct & 94 bp & $\begin{array}{c}\text { NM_000194 } \\
\text { (GenBank) }\end{array}$ \\
\hline
\end{tabular}

Accession numbers were taken from GenBank at the NCBI.

analysis/index.affx. Data were analyzed using Affymetrix Microarray Suite 5.0. Using the Affymetrix Data Mining Tool 3.0, gene expression was evaluated, and genes with at least a significant change in signal intensity of two-fold or greater were considered regulated. The entire data set is published in a MIAME compliant format in the GEO database (http://www.ncbi.nlm.nih.gov/geo/) under acc no GSE8908.

\section{Real-time RT-PCR}

For verification of the microarray data, genes of interest were chosen and primers (forward and reverse) were designed with the help of the primer ${ }^{3}$ shareware of the Whitehead Institute for Biomedical Research (http://frodo.wi.mit.edu/cgi-bin/primer3/ primer3_www.cgi). In these experiments, the same RNA was used as was used for microarray analysis. The RNA was reverse-transcribed with the help of the Advantage ${ }^{\circledR}$ RT-for-PCR kit (BD Biosciences, San Diego, CA, USA) with the help of Moloney Murine Leukemia Virus reverse transcriptase and oligo- $(\mathrm{dT})_{18}$-primers. The primers were synthesized by Operon (Operon Biotechnologies $\mathrm{GmbH}$, Cologne, Germany) and the sequences of the primers used are listed in Table 1. These primers were taken to perform fluorescent-based real-time reverse transcription polymerase chain reaction (real-time RT-PCR) quantification using the Mastercycler ep Realplex S (Eppendorf, Hamburg, Germany). Reagents (RealMaster Mix) were obtained from the same company and were applied as described by the manufacturer.

To optimize the real-time reverse transcription (RT) - PCR conditions for quantification, the optimal $\mathrm{MgCl}_{2}$ concentration was determined and the gradient function was applied to determine the proper annealing temperature for each primer. $12.5 \mu \mathrm{L}$ of RealMasterMix $^{\mathrm{TM}}$ SYBR $^{\circledR}$ Green PCR Master Mix (Eppendorf), 20 pmol of each primer, and $250 \mathrm{ng}$ of cDNA were added to a final volume of $25 \mu \mathrm{L}$. Cycling was performed as described below. After an initial activation step of $15 \mathrm{~min}$ at $95^{\circ} \mathrm{C}$, further steps were as follows : 45 cycles of denaturing $\left(30 \mathrm{sec}\right.$ at $\left.94^{\circ} \mathrm{C}\right)$, annealing (30 sec at annealing temperature (Table 1)), and elongation $\left(30 \mathrm{sec}\right.$ at $\left.72^{\circ} \mathrm{C}\right)$, and, lastly, an extension of $10 \mathrm{~min}$ at $72^{\circ} \mathrm{C}$.

Data acquisition was conducted after each extension step, and a melting curve was performed in 0.3 ${ }^{\circ} \mathrm{C}$ steps from $50-95^{\circ} \mathrm{C}$. Real-time RT-PCR efficiencies were calculated from the given slopes using Mastercycler ep Realplex S software. Real-time RT-PCR efficiency rates were high (values of 2.01). Experiments were performed in triplicate. The inter-test variation was $\leq 2 \%$, and the intra-test variation was $\leq 1 \%$. The PCR products were sequenced (Sequlab, Goettingen, Germany) to confirm their identity and melting curves were performed for each PCR. The relative ratios were calculated according to the algorithm of $\mathrm{Pfaffl}^{29)}$. The calibrator curve, obtained by the correlation of the threshold cycle values with the dilution series of the housekeeping gene hypoxanthine phosphoribosyltransferase 1 (HPRT1), exhib- 


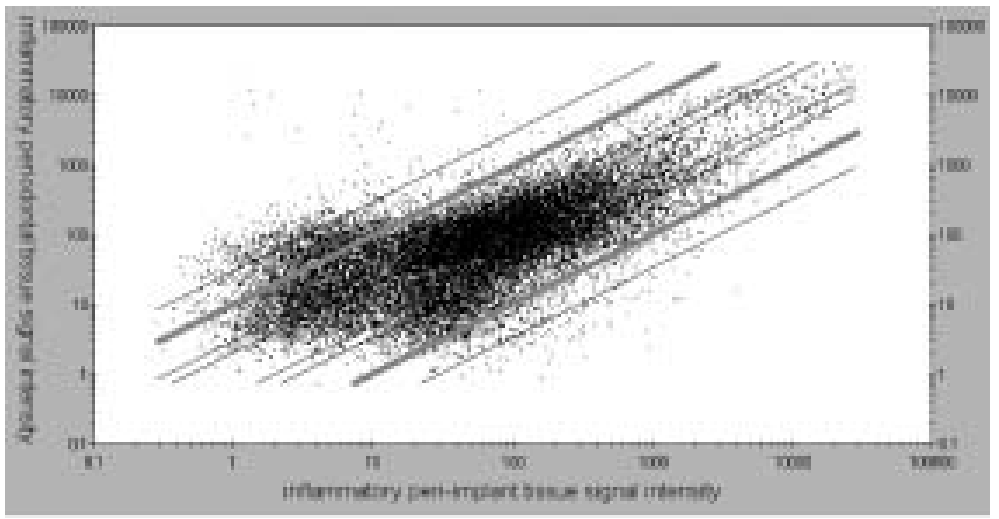

Fig. 1 Differential expression between inflammatory peri-implant and inflammatory periodontal tissue

Software used was GCOS1.2. Forward gridlines indicate expression ratios between the two probes. Each dot represents signal intensity measurement for a gene. The gray lines present the thresholds of two-fold differential expression.

ited a low $(\leq 1 \%)$ inter-test variation.

\section{Results}

\section{Quality control of human peri-implant and PDL cell mRNAs}

Prior to microarray analysis, we tested total RNA extracted from healthy PDL and chronically inflamed peri-implant and PDL tissues to validate the amount of nuclear factor kappa $\mathrm{B}(\mathrm{NF} \kappa \mathrm{B})$ by real-time RT$\mathrm{PCR}$. NF $\kappa \mathrm{B}$ plays a key role in regulating the immune response to infection. It controls many genes involved in inflammation and is found to be chronically active in many inflammatory diseases, such as periodontitis and peri-implantitis ${ }^{30)}$. An increase in fluorescence for the amplification of $\mathrm{NF} \kappa \mathrm{B}$ indicated the presence of mRNA for $\mathrm{NF} \kappa \mathrm{B}$ in inflamed periimplant and periodontal tissues. In contrast, no $\mathrm{NF} \kappa \mathrm{B}$ mRNA was detected in healthy periodontal tissue (data not shown).

\section{Microarray analysis}

With the help of microarray technology, gene expression profiling of chronically inflamed human peri-implant tissue was compared to the gene expression profile in chronically inflamed human PDL tissue. Expression rates of 14,239 genes were investi- gated and 2,079 of them were found to be differentially expressed by at least two-fold. The expression rates of 1,093 genes were significantly upregulated, and the expression rates of 986 genes were significantly downregulated in inflamed peri-implant tissue compared to inflamed PDL tissue (Fig. 1).

To further characterize the genetic data, we used Onto-Express ${ }^{31)}$ to classify genes according to the following Gene-Ontology (GO) categories ${ }^{32)}$ : molecular function, biological process and cellular component. The number of genes corresponding to each GO category among the 2,079 differentially expressed genes was tallied and compared to the number of genes expected for each GO category based on their representation on the Affymetrix HG_U133A 2.0 array. Significant differences from the expected were calculated with a binomial distribution. False discovery rates were also calculated based upon the number of GO categories with at least 1 gene in the list of 2,079 differentially expressed genes ${ }^{33)}$. Table 2 shows all GO functional classes with a $p<1.00 \mathrm{E}-5$, the false discovery rate for that class, as well as the number of genes corresponding to each GO functional class identified in our differentially expressed gene list. Once gene classes of the differentially expressed genes were highlighted, we decided to further examine the underlying biological phenomena. The previous 
Table 2 Functional gene classes demonstrating significant differential expression between peri-implantitis and periodontitis, using peri-implantitis as the baseline

Molecular function

\begin{tabular}{lccc}
\hline Function name & Total & P & FDR \\
\hline Protein binding & 442 & $1.06 \mathrm{E}-9$ & $1.18 \mathrm{E}-6$ \\
RNA binding & 103 & $1.14 \mathrm{E}-8$ & $6.35 \mathrm{E}-6$ \\
Structural constituent of ribosome & 46 & $3.97 \mathrm{E}-8$ & $1.47 \mathrm{E}-5$ \\
Structural constituent of cytoskeleton & 34 & $4.63 \mathrm{E}-7$ & $1.29 \mathrm{E}-4$ \\
MHC class II receptor activity & 10 & $2.61 \mathrm{E}-5$ & 0,00531 \\
Voltage-gated ion-selective channel activity & 5 & $2.87 \mathrm{E}-5$ & 0,00531 \\
Antigen binding & 11 & $5.75 \mathrm{E}-5$ & 0,00913 \\
\hline
\end{tabular}

Biological Process

\begin{tabular}{lccc}
\hline Function name & Total & P & FDR \\
\hline Protein biosynthesis & 70 & $1.49 \mathrm{E}-8$ & $2.54 \mathrm{E}-5$ \\
ER to Golgi vesicle-mediated transport & 27 & $9.12 \mathrm{E}-7$ & $7.79 \mathrm{E}-4$ \\
Nuclear mRNA splicing, via spliceosoma & 40 & $2.03 \mathrm{E}-6$ & 0,00105 \\
Immune response & 65 & $2.48 \mathrm{E}-6$ & 0,00105 \\
Cell fate determination & 8 & $3.12 \mathrm{E}-6$ & 0,00106 \\
Synaptic transmission & 5 & $2.10 \mathrm{E}-5$ & 0,00597 \\
Antigen presentation, exogenous antigen & 10 & $2.62 \mathrm{E}-5$ & 0,00638 \\
Antigen processing, exogenous antigen via MHC class II & 10 & $3.77 \mathrm{E}-5$ & 0,00735 \\
Cell motility & 33 & $4.01 \mathrm{E}-5$ & 0,00735 \\
Intracellular protein transport & 39 & $4.32 \mathrm{E}-5$ & 0,00735 \\
Cell homeostasis & 4 & $4.74 \mathrm{E}-5$ & 0,00735 \\
Negative regulation of cell proliferation & 40 & $7.44 \mathrm{E}-5$ & 0,01058 \\
\hline
\end{tabular}

Cellular Component

\begin{tabular}{lccc}
\hline Function name & Total & P & FDR \\
\hline Ribosome & 38 & $9.85 \mathrm{E}-7$ & $3.96 \mathrm{E}-4$ \\
Mitochondrial outer membrane & 14 & $3.05 \mathrm{E}-6$ & $6.13 \mathrm{E}-4$ \\
COPII vesicle coat & 8 & $1.81 \mathrm{E}-5$ & 0,00242 \\
Membrane & 433 & $5.23 \mathrm{E}-5$ & 0,00516 \\
Endoplasmic reticulum & 80 & $6.43 \mathrm{E}-5$ & 0,00516 \\
\hline
\end{tabular}

Total, Total number of genes identified in list of 2,079 differentially expressed genes corresponding to specific Gene Ontology classification; $\mathrm{P}$, Binomial distribution $p$-value ; FDR, Adjusted $p$-value using FDR correction ${ }^{27)}$.

genetic approach considers each biological process to be independent of each other and ignores any interaction among them ${ }^{33)}$. To identify pathways relevant to peri-implantitis and periodontitis, we considered Kyoto Encyclopedia of Genes and Genome (KEGG) as repository of pathways, which provides a database of metabolic, regulatory, and disease pathways (http: www.genome.jp $/ \mathrm{kegg} /$ ). It contains approximately 250 canonical signalling and metabolic pathways. To analyze the pathways, we used an impact analysis as approach, performed with Pathway Express (PE). It assesses the probability of having the observed num- 
Table 3 KEGG biological pathways for differentially expressed genes

\begin{tabular}{llcccl}
\hline Pathway Name & $\begin{array}{l}\text { Impact } \\
\text { Factor }\end{array}$ & $\begin{array}{l}\text { \#Genes in } \\
\text { Pathway }\end{array}$ & $\begin{array}{l}\text { \#Input Genes } \\
\text { in Pathway }\end{array}$ & $\begin{array}{c}\text { \#Pathway Genes } \\
\text { on Chip }\end{array}$ & $p$-value \\
\hline Antigen processing and presentation & 56,632 & 86 & 21 & 79 & 0,001499112 \\
Cell adhesion molecules (CAMs) & 24,051 & 132 & 26 & 119 & 0,008381183 \\
Focal adhesion & 13,867 & 194 & 48 & 185 & $4,43 \mathrm{E}-06$ \\
Natural killer cell mediated cytotoxicity & 7,533 & 128 & 26 & 115 & 0,00526794 \\
Tight junction & 7,187 & 119 & 24 & 107 & 0,007925817 \\
Insulin signaling pathway & 6,08 & 135 & 27 & 129 & 0,012968155 \\
Regulation of actin cytoskeleton & 5,972 & 206 & 37 & 186 & 0,009654648 \\
Leukocyte transendothelial migration & 5,54 & 117 & 22 & 107 & 0,028073545 \\
Adherens junction & 5,368 & 77 & 17 & 75 & 0,02087704 \\
ECM-receptor interaction & $\mathbf{5 , 0 8 3}$ & $\mathbf{8 7}$ & $\mathbf{1 8}$ & $\mathbf{8 2}$ & $\mathbf{0 , 0 2 4 2 5 8 6 0 2}$ \\
GnRH signaling pathway & 4,868 & 97 & 17 & 92 & 0,110781952 \\
MAPK signaling pathway & 4,657 & 273 & 44 & 256 & 0,054721468 \\
TGF-beta signaling pathway & 4,6 & 84 & 17 & 78 & 0,029872341 \\
Wnt signaling pathway & 4,381 & 147 & 25 & 130 & 0,042402693 \\
VEGF signaling pathway & 4,299 & 72 & 14 & 68 & 0,069134171 \\
Cell cycle & 3,73 & 112 & 20 & 103 & 0,059100576 \\
Toll-like receptor signaling pathway & 3,4 & 91 & 16 & 85 & 0,105242666 \\
\hline
\end{tabular}

ber of differentially expressed genes on a given pathway just by chance ${ }^{34,35)}$. It takes into consideration the number of differentially expressed genes on each pathway, the position of the genes within the pathway, and the signalling interactions between various genes as described by the pathway. Signalling interaction refers to the situation in which the change in the activity of a given gene affects the expression of another gene in a consistent way. An impact value and probability value are assigned to each pathway. The impact factor indicates the relative importance of each pathway identified.

Table 3 depicts pathways highlighted by $\mathrm{PE}$ and ordered by their impact factor. Specifically, we focused on the ECM-receptor interaction pathway (Fig. 2). In this pathway, 82 probed genes out of 87 specific pathway genes were expressed in both tissues, and 18 probed genes were differentially expressed between either peri-implant or periodontal tissue.

The analysis of ECM molecules and their receptors showed that the expression rates of the laminin chains, alpha2 (3 fold more), alpha3 (3 fold more), and beta1 (5.5 fold more), were the only upregulated genes in the laminin family in inflamed peri-implant tissue as compared to inflamed PDL tissue (Table 4). In the family of collagens, the mRNA expression of collagen types III (3.6 fold less) and XI (2.4 fold less) were significantly down-regulated in the inflamed peri-implant tissue, while the genes of collagen types IV (48.5 fold more), VI (20.5 fold more), III (21.7 fold more), and XVII (43.4 fold more) were significantly upregulated during peri-implant inflammation. The integrins alpha9 (18 fold more), beta2 (3 fold more), and beta4 ( 15.3 fold more) showed an increase and the integrins alphaV (3.4 fold less), alpha6 (4.8 fold less), and beta1 ( 5 fold less) showed a decrease in their gene expression rates in inflamed peri-implant tissue as compared to inflamed PDL tissue. The remaining integrin subunits were expressed in equal amounts.

The analysis of matrix degrading enzymes showed that increased gene expression of cathepsin D (2.4 fold more) and cathepsin S (23.3 fold more) as well as decreased gene expression of cathepsin B (2.9 fold less) was observed in inflamed peri-implant tissue. Furthermore, the mRNAs of ADAM15 (5 fold more), ADAM17 (34.5 fold more), and ADAMTS6 (6.6 fold more) were significantly up-regulated during periimplant inflammation. The collagenase MMP14 gene 


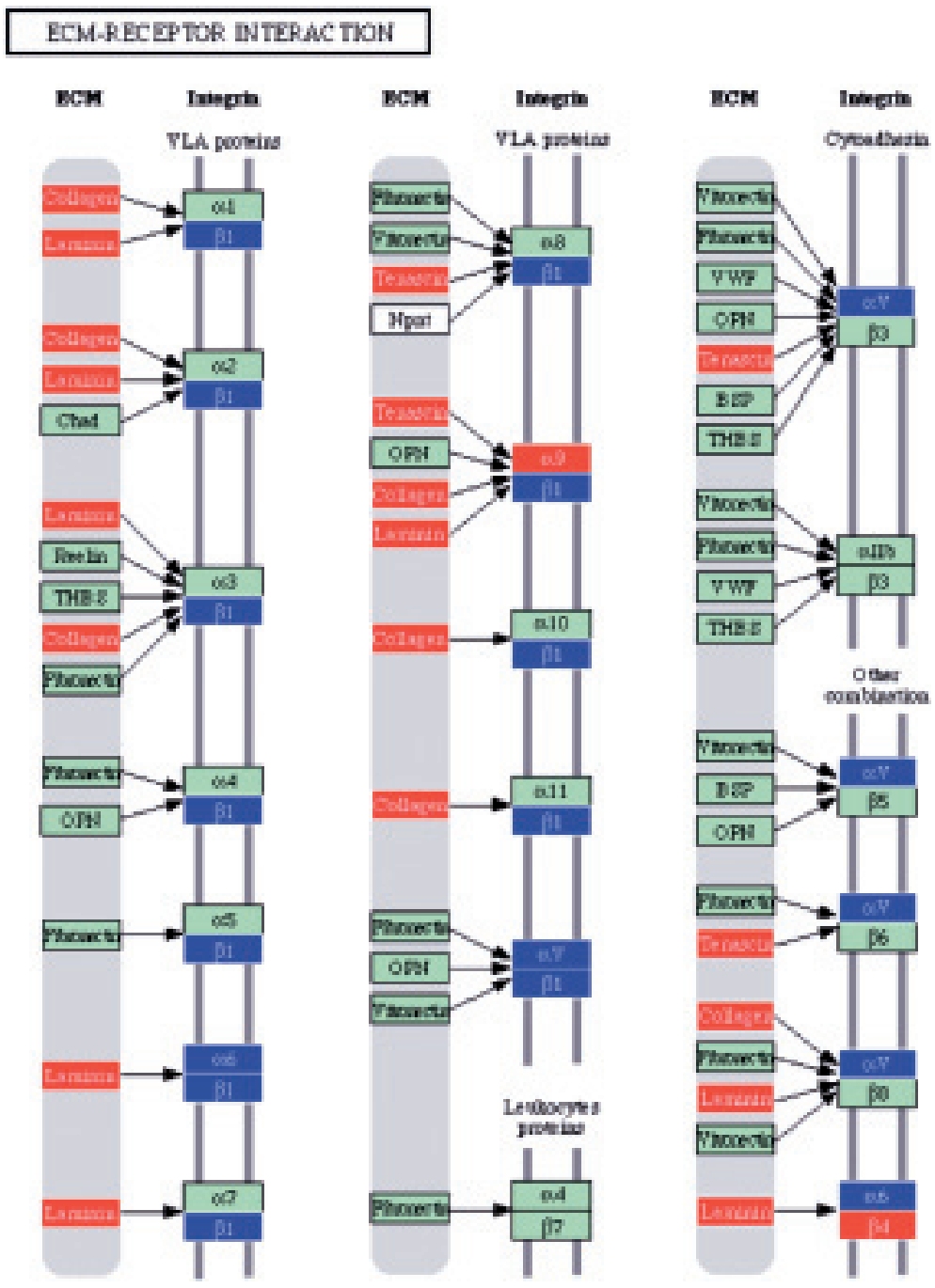

Fig. 2 Modified "ECM-receptor interaction" (04512hsa) pathway from KEGG

Protein symbols were replaced by gene symbols to reflect genecentric data. The red show up-regulated and the blue show downregulated genes.

was expressed at least twenty-three fold more, while the expression rates of the rest of the MMPs were unchanged. Nevertheless, the gene expression of two of the four tissue inhibitors of the matrix metalloproteinases (TIMPs), namely TIMP1 (4.7 fold more) and TIMP3 (14.9 fold more), were up-regulated in inflamed peri-implant tissue. A complete listing of differentially regulated genes is provided as supplemental information. The entire data set is published in a minimum information about a microarray experiment
(MIAME) compliant format in the gene expression omnibus (GEO) database (http://www.ncbi.nlm.nih. gov/geo/) under acc no GSE8908.

\section{Real-time RT-PCR analysis}

To validate the gene expressions observed in the microarray analysis, we studied four genes of interest by real-time RT-PCR (collagen type $\mathrm{I}$, integrin alpha6, integrin beta1, and integrin beta4). Both inflamed peri-implant tissue and PDL tissue were 
Table 4 Differentially expressed genes between chronically inflamed peri-implant and chronically inflamed PDL tissue by DNA microarray

Up-regulated in inflamed peri-implant tissue

\begin{tabular}{lcl}
\hline Name & Fold change & Description \\
\hline LAMA2 & 3 & laminin alpha2 \\
LAMA3 & 3 & laminin alpha3 \\
LAMB1 & 5.5 & laminin beta1 \\
COL4A2 & 48.5 & collagen type IV, alpha 2 \\
COL6A2 & 20.5 & collagen type VI, alpha 2 \\
COL7A1 & 21.7 & collagen type VII, alpha 1 \\
COL17A1 & 43.4 & collagen type XII, alpha 1 \\
ITGA9 & 18 & integrin alpha9 \\
ITGB2 & 3 & integrin beta2 \\
ITGB4 & 15.3 & integrin beta4 \\
ADAMTS6 & 6.6 & A disintegrin and metalloprotease domain with thrombospondin type I motifs domain 6 \\
ADAM15 & 5 & A disintegrin and metalloproteinase domain 15 \\
ADAM17 & 34.5 & A disintegrin and metalloproteinase domain 17 \\
MMP14 & 23.1 & matrix metalloproteinase 14 \\
TIMP1 & 4.7 & tissue inhibitor of metalloproteinase 1 \\
TIMP3 & 14.9 & tissue inhibitor of metalloproteinase 3 \\
CTSD & 2.4 & cathepsin D \\
CTSS & 23.3 & cathepsin S \\
\hline
\end{tabular}

Down-regulated in inflamed peri-implant tissue

\begin{tabular}{lcl}
\hline Name & Fold change & Description \\
\hline COL3A1 & -3.6 & collagen type III, alpha 1 \\
COL11A1 & -2.4 & collagen type XI, alpha 1 \\
ITGA6 & -4.8 & integrin alpha6 \\
ITGAV & -3.4 & integrin alphaV \\
ITGB1 & -5 & integrin beta1 \\
ADAM9 & -11.1 & A disintegrin and metalloproteinase domain 9 \\
ADAM10 & -4.7 & A disintegrin and metalloproteinase domain 10 \\
CTSB & -2.9 & cathepsin B \\
\hline
\end{tabular}

compared with healthy PDL tissue, and, in a second step, the relative ratios of both forms of diseases were compared to each other.

Compared with healthy PDL tissue, the mRNA expression of collagen type IV was increased in chronically inflamed PDL tissue (16.3 fold) and was increased in chronically inflamed peri-implant tissue (24.5 fold). Consequently, collagen type IV mRNA was significantly increased in its expression rate in peri-implant tissue compared with PDL tissue.
Compared with healthy PDL tissue, the integrin alpha6 gene was up-regulated 5.3 and 11.6 fold in inflamed peri-implant tissue (5.3 fold more) and PDL tissue (11.6 fold more), respectively. With respect to each other, its expression was down-regulated 6.3 fold in peri-implant tissue.

The integrin beta1 as well as the integrin beta4 mRNA expression rates were unchanged in chronically inflamed peri-implant tissue compared with inflamed PDL tissue in vivo. For the chosen genes, 
the microarray data are in agreement with the realtime RT-PCR results.

\section{Discussion}

Loosening of dental implants is an important clinical problem. The microbial flora in the natural dentition sulcus/pocket and the implant crevice/pocket is thought to behave similarly in both health and disease $^{1)}$. Thus, peri-implant pathogenic bacteria cause an adverse host response in peri-implant tissues. These adverse host responses lead to activation of multiple biological and pathological processes. The pathological feature is the progressive loss of peri-implant support tissues, in which many proteolytic enzymes participate.

A major challenge for researchers who analyze gene expression microarray data is to make biological sense of the large amounts of information gained from these experiments. The comprehensive approach of gene expression analysis, utilizing annotated pathways rather than isolated genes, provides a greater understanding of the processes that may be involved in peri-implant inflammation in vivo. We grouped the data according to GO categories and analyzed those biological processes, molecular functions, and cellular components that have a number of differentially expressed genes. Our study is the first to show that the highlighted processes and functions play a differential role in the comparison between peri-implantitis and periodontitis. Interestingly, functions linked to protein production are higher in peri-implantitis as compared to periodontitis. As a matter fact, protein biosynthesis has a $p$-value of $1.49 \mathrm{E}-8$. Additionally, we analyzed biological pathways to highlight those with a number of differentially expressed genes. We focused on the ECM-receptor interaction pathway. An impact factor of 5.083 was calculated for this pathway with high biological meaning in peri-implant inflammation. As a result, we focused on the analysis of molecules in this pathway, as well as some of the enzymes playing a role in ECM degradation. We are aware of the fact that mRNA detection does not automatically mean that the corresponding protein is translated or secreted. In the following, we discuss possible roles of the investigated genes, assuming that the mRNA amounts correlate to protein amounts in peri-implant tissue as well as in the PDL.

During inflammation of tooth-supporting structures, basement membrane components were observed at abnormal sites in the stroma of chronic periodontal inflammation. Therefore, they might serve as adhesive ligands for various cell types in the inflamed $\mathrm{PDL}^{36)}$. The comparison of the gene expressions of healthy and inflamed PDL tissue in vivo showed that the laminin chain mRNAs alpha2, alpha4, beta1, beta2 and gamma3 were down-regulated and the laminin beta3 chain gene was up-regulated in inflamed PDL tissue (unpublished results). The increased expression of the laminin beta3 chain during chronic periodontal inflammation may suggest a role for laminin-332, which induces the apical migration of epithelial cells in periodontitis ${ }^{37)}$. In the present work, we show that in inflamed peri-implant tissue, the expression rates of the laminin chains alpha2, alpha3 and beta1 were increased relative to inflamed PDL tissue, suggesting a role for the laminins laminin-211, laminin-213, and laminin-311 during chronic peri-implant inflammation ${ }^{38)}$. Here, they might serve as adhesive ligands for various cell types in the inflamed peri-implant tissue.

The immunohistochemical comparison of healthy human peri-implant versus periodontal gingival tissues showed higher amounts of collagen type $\mathrm{V}$ in peri-implant keratinized gingival connective tissue ${ }^{39)}$. During bone healing, the final goal of the expression of different collagen genes is the production of osteoid, the mineralizing bone matrix that eventually restores bone integrity ${ }^{40)}$. Thus, changes from mesenchyme to bone during peri-implant tissue healing involve many different ECM molecules as well as major changes in the expression of several collagen genes. Based on their supramolecular structures, the collagens are divided into two main classes: fibrilforming (fibrillar) collagens, comprising types I, II, III, V, and XI, as well as non-fibril-forming collagens, including the other known collagen types ${ }^{41}$. The former group leads to the slow re-modeling of tissue and contains rodlike molecules with long, continuous triple helices, which are the constituents of 
banded collagen fibrils, giving tensile strength to tissues. The non-fibril-forming collagens form a heterogeneous group of supramolecular structures and networks ${ }^{40)}$. We showed that the mRNAs of the collagen types IV, VI, VII, and XVII are increased and the mRNAs of the collagen types III and XI are decreased in inflamed peri-implant tissue compared with inflamed periodontal tissue. Therefore, only genes of non-fibril-forming collagens (types IV, VI, VII, and XVII) are increased, whereas only genes of two fibril-forming collagens (types III and XI) were decreased, indicating that peri-implant tissue may be, in comparison to periodontal tissue, a non-fibril-forming collagenricher tissue and re-model faster.

Periodontal inflammation involves alterations in both cell adhesion ligands and receptors ${ }^{36)}$. Our study showed that the expression of diverse integrins is altered during peri-implant inflammation compared with periodontal inflammation in vivo. The integrins alpha9, beta2, and beta4 were significantly up-regulated and the genes of the integrins alpha6, alphaV, and beta 1 were down-regulated during peri-implant disease, suggesting that these integrins might serve as new adhesive ligands for various cell types in inflamed peri-implant tissue.

MMPs, ADAMs, cathepsins and other proteases play a role in the degradation of ECM and other cell proteins $^{42,43)}$. We investigated the gene expression levels of all known MMPs, $\operatorname{ADAM}(\mathrm{TS}) \mathrm{s}$, and cathepsins. In the family of MMPs, the MMP14 gene was the only up-regulated mRNA in inflamed periimplant tissue compared with periodontal tissue. MMP14 is widely expressed in most tissues in different species as well as in humans ${ }^{44)}$. A high level of MMP14 mRNA is detected during rat skin wound healing ${ }^{45)}$. In humans, MMP14 is mainly expressed in mesenchymal tissues of embryos such as bone, muscle and fibroblastic tissues ${ }^{46)}$. MMP14 is considered to be involved in the degradation of various ECM components, including collagens type I, II, and III, laminins laminin-111 and laminin-332, nidogens, vitronectin, fibronectin, fibrin and proteoglycans ${ }^{47)}$.

TIMPs are natural inhibitors of the matrix metalloproteinases, which exhibit multiple biochemical and physiological/biological functions including inhibition of active MMPs, pro-MMP activation, cell growth promotion, matrix binding and turnover, inhibition of angiogenesis, tumor metastasis and the induction of apoptosis $^{48)}$. Our investigations showed increases in TIMP1 and TIMP3 expression in inflamed periimplant tissue in vivo. These results indicate that peri-implant tissue might be an active source of MMP14 mRNA production in response to chronic inflammation and, hence, the increase in TIMP1 and TIMP3 concentrations in chronic peri-implant disease suggests maintenance of the balance between the amount of MMPs and their inhibitors.

Members of the ADAM and a disintegrin and metalloproteinase with a thrombospondin type 1 motif (ADAMTS) family of proteinases, namely the mRNAs of ADAM15, ADAM17 and ADAMTS6, were significantly up-regulated while ADAM9 and ADAM10 were down-regulated in peri-implant tissue compared with periodontal tissue in vivo, suggesting a role for ADAM15, ADAM17, and ADAMTS6 in tissue destruction during peri-implant disease.

Cathepsins are thought to contribute to periodontal destruction during periodontitis ${ }^{25)}$. Increases in the level and activity of several cathepsins have been shown in periodontitis ${ }^{49)}$. In chronically inflamed periimplant tissue, cathepsin $\mathrm{D}$ and cathepsin $\mathrm{S}$ genes were increased and the cathepsin $\mathrm{B}$ gene expression was decreased compared to inflamed periodontal tissue. Increased expression of cathepsin D and cathepsin S might indicate a role for the development and progression of peri-implantitis. The decrease of the cathepsin B indicates that this enzyme may be less important during peri-implant inflammation, which is different from periodontal inflammation (unpublished results).

After pooling the samples the individual variability of gene expression is lost. We are aware of the fact that one peri-implant tissue may exhibit gene expression patterns that resemble those found in periodontitis tissue sample, but the probability that this happens is rather low in the case of genes highlighted here. Obviously, every biological level of organization results in variation in gene expression. And human tissues often have a high level of sample-to-sample variability due to a high level of patient variability. 
Pooling is one of the more common variance mitigation strategies.

\section{Conclusions}

In summary, this work is the first to compare the gene expression profiles of chronically inflamed periimplant and chronically inflamed PDL tissue by means of whole genome microarray and real-time RT-PCR. The analysis of different functional gene classes demonstrated significant differential expression between peri-implantitis and periodontitis in vivo and the pathway analysis highlighted pathways with a number of differentially expressed genes. Therefore, the broad information gained shows that peri-implantitis and periodontitis are two distinct disease entities at the mRNA level.

\section{Acknowledgements}

The authors would like to thank Boguscha Sadowski for her excellent technical assistance. Sections of this work were taken from the doctoral theses of Rasco Brietze, Frederic vom Orde, and Sebastian Szydlik. The work was supported by the Research program, Faculty of Medicine, GeorgAugust-University Goettingen to Nikolaus Gersdorff (\#140 1490) and by a grant from the Deutsche Gesellschaft fuer Implantologie (DGI) to Nikolaus Gersdorff (DGI-13 4708 0).

\section{Description of Additional Data Files}

The entire data set is published in a MIAME compliant format in the GEO database under acc no GSE8908. At the moment, the data is still private. The referees have to subscribe to http://www.ncbi. nlm.nih.gov/geo/query/acc.cgi? acc $=$ GSE8908.

User : reviewer_ac

Password : 476829599

\section{References}

1) Meffert, R. M. : Periodontitis vs. peri-implantitis : The same disease? The same treatment? Crit. Rev.
Oral Biol. Med. 7 : 278—291, 1996.

2) Albrektsson, T. and Isidor, F. : Consensus report of session IV. In Proceedings of the first european workshop on periodontology. (eds. Lang, N. P. and Karring, T.), pp.365-369, Quintessence, London, 1994.

3) Liu, F., Malaval, L., Gupta, A. K. and Aubin, J. E. : Simultaneous detection of multiple bone-related mRNAs and protein expression during osteoblast differentiation : polymerase chain reaction and immunocytochemical studies at the single cell level. Dev. Biol. 166 : 220-234, 1994.

4) Roche, P., Goldberg, H. A., Delmas, P. D. and Malaval, L. : Selective attachment of osteoprogenitors to laminin. Bone 24:329-336, 1999.

5) Klein, M. O., Reichert, C., Koch, D., Horn, S. and AlNawas, B. : In vitro assessment of motility and proliferation of human osteogenic cells on different isolated extracellular matrix components compared with enamel matrix derivative by continuous single-cell observation. Clin. Oral Impl. Res. 18 : 40-45, 2007.

6) Aumailley, M., Bruckner-Tuderman, L., Carter, W. G., Deutzmann, R., Edgar, D., Ekblom, P., Engel, J., Engvall, E., Hohenester, E., Jones, J. C. R., Kleinman, H. K., Marinkovich, M. P., Martin, G. R., Mayer, U., Meneguzzi, G., Miner, J. H., Miyazaki, K., Patarroyo, M., Paulsson, M., Quaranta, V., Sanes, J. R., Sasaki, T., Sekiguchi, K., Sorokin, L. M., Talts, J. F., Tryggvason, K., Uitto, J., Virtanen, I., von der Mark, K., Wewer, U. M., Yamada, Y. and Yurchenco, P. D. : A simplified laminin nomenclature. Matrix Biol. 24 : 326-332, 2005.

7) Timpl, R. : Macromolecular organization of basement membranes. Curr. Opin. Cell Biol. 8:618-624, 1996.

8) Ryan, M. C. and Christiano, A. M. : The functions of laminins : Lessons from in vivo studies. Matrix Biol. $15: 369-381,1996$.

9) Miner, J. H. and Yurchenco, P. D. : Laminin functions in tissue morphogenesis. Annu. Rev. Cell Dev. Biol. 20:255-284, 2004.

10) Engvall, E. and Wewer, U. M. : Domains of laminin. J. Cell Biochem. $61:$ 493-501, 1996.

11) Tunggal, P., Smyth, N., Paulsson, M. and Ott, M.C. : Laminins: Structure and genetic regulation. Microsc. Res. Tech. 51 : 214-227, 2000.

12) Gersdorff, N., Kohfeldt, E., Sasaki, T., Timpl, R. and Miosge, N. : Laminin gamma3 chain binds to nidogen and is located in murine basement membranes. J. Biol. Chem. 280：22146—22153, 2005. 
13) Hay, E. D. : Cell Biology of extracellular matrix (ed. Hay, E. D.), Plenum Press, New York, 1991.

14) Veit, G., Kobbe, B., Keene, D. R., Paulsson, M., Koch, M. and Wagener, R. : Collagen XXVIII, a novel von willebrand factor A domain-containing protein with many imperfections in the collagenous domain. J. Biol. Chem. 281 : 3494-3504, 2006.

15) Plumb, D. A., Dhir, V., Mironov, A., Ferrara, L., Poulsom, R., Kadler, K. E., Thornton, D. J., Briggs, M. D. and Boot-Handford, R. P. : Collagen XXVII is developmentally regulated and forms thin fibrillar structures distinct from those of classical vertebrate fibrillar collagens. J. Biol. Chem. 282 : 12791-12795, 2007.

16) Plow, E. F., Haas, T. A., Zhang, L., Loftus, J. and Smith, J. W. : Ligand binding to integrins. J. Biol. Chem. 275:21785-21788, 2000.

17) Venter, J. C., Adams, M. D., Myers, E. W., Li, P. W., Mural, R. J., Sutton, G. G., Smith, H. O., Yandell, M., Evans, C. A., Holt, R. A., Gocayne, J. D., Amanatides, P., Ballew, R. M., Huson, D. H., Wortman, J. R., Zhang, Q., Kodira, C. D., Zheng, X. H., Chen, L., Skupski, M., Subramanian, G., Thomas, P. D., Zhang, J., Gabor Miklos, G. L., Nelson, C., Broder, S., Clark, A. G., Nadeau, J., McKusick, V. A., Zinder, N., Levine, A. J., Roberts, R. J., Simon, M., Slayman, C., Hunkapiller, M., Bolanos, R., Delcher, A., Dew, I., Fasulo, D., Flanigan, M., Florea, L., Halpern, A., Hannenhalli, S., Kravitz, S., Levy, S., Mobarry, C., Reinert, K., Remington, K., Abu-Threideh, J., Beasley, E., Biddick, K., Bonazzi, V., Brandon, R., Cargill, M., Chandramouliswaran, I., Charlab, R., Chaturvedi, K., Deng, Z., Di Francesco, V., Dunn, P., Eilbeck, K., Evangelista, C., Gabrielian, A. E., Gan, W., Ge, W., Gong, F., Gu, Z., Guan, P., Heiman, T. J., Higgins, M. E., Ji, R. R., Ke, Z., Ketchum, K. A., Lai, Z., Lei, Y., Li, Z., Li, J., Liang, Y., Lin, X., Lu, F., Merkulov, G. V., Milshina, N., Moore, H. M., Naik, A. K., Narayan, V. A., Neelam, B., Nusskern, D., Rusch, D. B., Salzberg, S., Shao, W., Shue, B., Sun, J., Wang, Z., Wang, A., Wang, X., Wang, J., Wei, M., Wides, R., Xiao, C., Yan, C., Yao, A., Ye, J., Zhan, M., Zhang, W., Zhang, H., Zhao, Q., Zheng, L., Zhong, F., Zhong, W., Zhu, S., Zhao, S., Gilbert, D., Baumhueter, S., Spier, G., Carter, C., Cravchik, A., Woodage, T., Ali, F., An, H., Awe, A., Baldwin, D., Baden, H., Barnstead, M., Barrow, I., Beeson, K., Busam, D., Carver, A., Center, A., Cheng, M. L., Curry, L., Danaher, S., Davenport, L., Desilets, R., Dietz, S., Dodson, K., Doup, L., Ferri- era, S., Garg, N., Gluecksmann, A., Hart, B., Haynes, J., Haynes, C., Heiner, C., Hladun, S., Hostin, D., Houck, J., Howland, T., Ibegwam, C., Johnson, J., Kalush, F., Kline, L., Koduru, S., Love, A., Mann, F., May, D., McCawley, S., McIntosh, T., McMullen, I., Moy, M., Moy, L., Murphy, B., Nelson, K., Pfannkoch, C., Pratts, E., Puri, V., Qureshi, H., Reardon, M., Rodriguez, R., Rogers, Y. H., Romblad, D., Ruhfel, B., Scott, R., Sitter, C., Smallwood, M., Stewart, E., Strong, R., Suh, E., Thomas, R., Tint, N. N., Tse, S., Vech, C., Wang, G., Wetter, J., Williams, S., Williams, M., Windsor, S., Winn-Deen, E., Wolfe, K., Zaveri, J., Zaveri, K., Abril, J. F., Guigó, R., Campbell, M. J., Sjolander, K. V., Karlak, B., Kejariwal, A., Mi, H., Lazareva, B., Hatton, T., Narechania, A., Diemer, K., Muruganujan, A., Guo, N., Sato, S., Bafna, V., Istrail, S., Lippert, R., Schwartz, R., Walenz, B., Yooseph, S., Allen, D., Basu, A., Baxendale, J., Blick, L., Caminha, M., Carnes-Stine, J., Caulk, P., Chiang, Y. H., Coyne, M., Dahlke, C., Mays, A., Dombroski, M., Donnelly, M., Ely, D., Esparham, S., Fosler, C., Gire, H., Glanowski, S., Glasser, K., Glodek, A., Gorokhov, M., Graham, K., Gropman, B., Harris, M., Heil, J., Henderson, S., Hoover, J., Jennings, D., Jordan, C., Jordan, J., Kasha, J., Kagan, L., Kraft, C., Levitsky, A., Lewis, M., Liu, X., Lopez, J., Ma, D., Majoros, W., McDaniel, J., Murphy, S., Newman, M., Nguyen, T., Nguyen, N., Nodell, M., Pan, S., Peck, J., Peterson, M., Rowe, W., Sanders, R., Scott, J., Simpson, M., Smith, T., Sprague, A., Stockwell, T., Turner, R., Venter, E., Wang, M., Wen, M., Wu, D., Wu, M., Xia, A., Zandieh, A. and Zhu, X.: The sequence of the human genome. Science 291: 1304-1351, 2001.

18) Popova, S. N., Barczyk, M., Tiger, C. F., Beertsen, W., Zigrino, P., Aszodi, A., Miosge, N., Forsberg, E. and Gullberg, D. : Alpha11 beta1 integrin-dependent regulation of periodontal ligament function in the erupting mouse incisor. Mol. Cell Biol. 27 : 43064316, 2007.

19) Popova, S. N., Lundgren-Åkerlund, E., Wiig, H. and Gullberg, D. : Physiology and pathology of collagen receptors. Acta Physiol. 190 : 179-187, 2007.

20) Nishiuchi, R., Takagi, J., Hayashi, M., Ido, H., Yagi, Y., Sanzen, N., Tsuji, T., Yamada, M. and Sekiguchi, K. : Ligand-binding specificities of laminin binding integrins: a comprehensive survey of lamininintegrin interactions using recombinant alpha3beta1, alpha6beta1, alpha7beta1 and alpha6beta4 integrins. Matrix Biol. 25 : 189-197, 2006. 
21) Alcoforado, G. A., Rams, T. E., Feik, D. and Slots, J. : Microbial aspects of failing osseointegrated dental implants in humans. J. Parodontol. 10 : 11-18, 1991.

22) Smalley, J. W. : Pathogenic mechanisms in periodontal disease. Adv. Dent. Res. 8 : 320-328, 1994.

23) Alexander, C. M. and Werb, Z. : Extracellular matrix degradation. In : Cell biology of extracellular matrix (ed. Hay, E. D.), pp.255-302, Plenum Press, New York, 1991.

24) Birkedal-Hansen, H. : Host-mediated extracellular matrix destruction by metalloproteinases. In : Molecular pathogenesis of periodontal disease (ed. Genco, R.), pp.191-202, American Society of Microbiology, Washington DC, 1994.

25) Trabandt, A., Muller-Ladner, U., Kriegsmann, J., Gay, R. E. and Gay, S. : Expression of proteolytic cathepsins $\mathrm{B}, \mathrm{D}$, and $\mathrm{L}$ in periodontal gingival fibroblasts and tissues. Lab. Invest. $73: 205-212,1995$.

26) Strbac, G. D., Monov, G., Cei, S., Kandler, B., Watzek, G. and Gruber, R. : Cathepsin K levels in the crevicular fluid of dental implants : a pilot study. J. Clin. Periodontol. 33 : 302-308, 2006.

27) Schwarz, F., Herten, M., Sager, M., Bieling, K., Sculean, A. and Becker, J.: Comparison of naturally occurring and ligature-induced peri-implantitis bone defects in humans and dogs. Clin. Oral Implants Res. $18: 161-170,2007$.

28) Armitage, G. C. : Periodontal diagnoses and classification of periodontal diseases. Periodontol. $200034: 9$ $-21,2004$.

29) Pfaffl, M. W., Tichopad, A., Prgomet, C. and Neuvians, T. P. : Determination of stable housekeeping genes, differentially regulated target genes and sample integrity : BestKeeper-Excel-based tool using pairwise correlations. Biotechnol. Lett. 26:509-515, 2004.

30) Silva, N., Dutzan, N., Hernandez, M., Dezerega, A., Rivera, O., Aguillon, J. C., Aravena, O., Lastres, P., Pozo, P., Vernal R. and Gamonal, J. : Characterization of progressive periodontal lesions in chronic periodontitis patients: levels of chemokines, cytokines, matrix metalloproteinase-13, periodontal pathogens and inflammatory cells. J. Clin. Periodontol. 35:206 $-214,2008$.

31) Khatri, P., Voichita, C., Kattan, K., Ansari, N., Khatri, A., Georgescu, C., Tarca, A. L. and Draghici, S. : Onto-tools : New additions and improvements in 2006. Nucleic Acids Res. 35 (Web Server issue): W206-W211, 2007.
32) Benjamini, Y. and Hochberg, Y. : Controlling the false discovery rate: A practical and powerful approach to multiple testing. J. R. Stat. Soc. 57 : 289, 1995.

33) Khatri, P. and Draghici, S. : Ontological analysis of gene expression data : current tools, limitations, and open problems. Bioinformatics 21:3587-3595, 2005.

34) Draghici, S., Khatri, P., Tarca, A. L., Amin, K., Done, A., Voichita, C., Georgescu, C. and Romero, R. : A systems biology approach for pathway level analysis. Genome Res. 17 : 1537-1545, 2007.

35) Kanehisa, M. and Goto, S. : KEGG : Kyoto encyclopedia of genes and genomes. Nucleic Acids Res. 28 : $27-30,2000$.

36) Haapasalmi, K., Mäkelä, M., Oksala, O., Heino, J., Yamada, K. M., Uitto, V. J. and Larjava, H. : Expression of epithelial adhesion proteins and integrins in chronic inflammation. Am. J. Pathol. $147:$ 193-206, 1995.

37) Pollanen, M. T., Salonen, J. I. and Uitto, V. J. : Structure and function of the tooth-epithelial interface in health and disease. Periodontol. 2000 31:12-31, 2003.

38) Gu, Y.-C., Kortesmaa, K., Tryggvason, K., Persson, J., Ekblom, P., Jacobsen, S.-E. and Ekblom, M. : Laminin isoform-specific promotion of adhesion and migration of human bone marrow progenitor cells. Blood 101: 877-885, 2003.

39) Romanos, G. E., Schröter-Kermani, C., Weingart, D. and Strub, J. R. : Healthy human periodontal versus peri-implant gingival tissues: An immunohistochemical differentiation of the extracellular matrix. Int. J. Oral Maxillofac. Implants 10 : 750-758, 1995.

40) Sandberg, M. M., Aro, H. T. and Vuorio, E. I. : Gene expression during bone repair. Clin. Orthop. Relat. Res. 289 : 292-312, 1993.

41) Vuorio, F. and Crombrugghe, B. : The family of collagen genes. Annu. Rev. Biochem. 59 : 837-872, 1990.

42) Werb, Z. : ECM and cell surface proteolysis : regulating cellular ecology. Cell 91:439-442, 1997.

43) Van den Steen, P. E., Opdenakker, G., Wormald, M. R., Dwek, R. A. and Rudd, P. M. : Matrix remodelling enzymes, the protease cascade and glycosylation. Biochem. Biophys. Acta 1528 : 61-73, 2001.

44) Shofuda, K., Yasumitsu, H., Nishihashi, A., Miki, K. and Miyazaki, K. : Expression of three membranetype matrix metalloproteinases (MT-MMPs) in rat vascular smooth muscle cells and characterization of MT3-MMPs with and without transmembrane 
domain. J. Biol. Chem. 272 : 9749-9754, 1997.

45) Okada, A., Tomasetto, C., Lutz, Y., Bellocq, J. P., Rio, M. C. and Basset, P. : Expression of matrix metalloproteinases during rat skin wound healing : evidence that membrane type- 1 matrix metalloproteinase is a stromal activator of pro- gelatinase A. J. Cell. Biol. 137 : 67-77, 1997.

46) Sato, H., Takino, T., Okada, Y., Cao, J., Shinagawa, A., Yamamoto, E. and Seiki, M. : A matrix metalloproteinase expressed on the surface of invasive tumor cells. Nature 370 : 61-65, 1994.

47) Sternlicht, M. D. and Werb, Z. : How matrix metallo- proteinases regulate cell behavior. Annu. Rev. Cell Dev. Biol. 17 : 463-516, 2001.

48) Bigg, H. F., Morrison, C. J., Butler, G.S., Bogoyevitch, M. A., Wang, Z., Soloway, P. D. and Overall, C. M. : Tissue inhibitor of metalloproteinases -4 inhibits but does not support the activation of gelatinase A via efficient inhibition of membrane type 1-matrix metalloprotein-ase. Cancer Res. 61 : 3610-3618, 2001.

49) Chen, H. Y., Cox, S. W. and Eley, B. M. : Cathepsin B, alpha 2-macroglobulin and cystatin levels in gingival crevicular fluis from chronic periodontitis patients. J. Clin. Periodontol. 25 : 34-41, 1998. 